
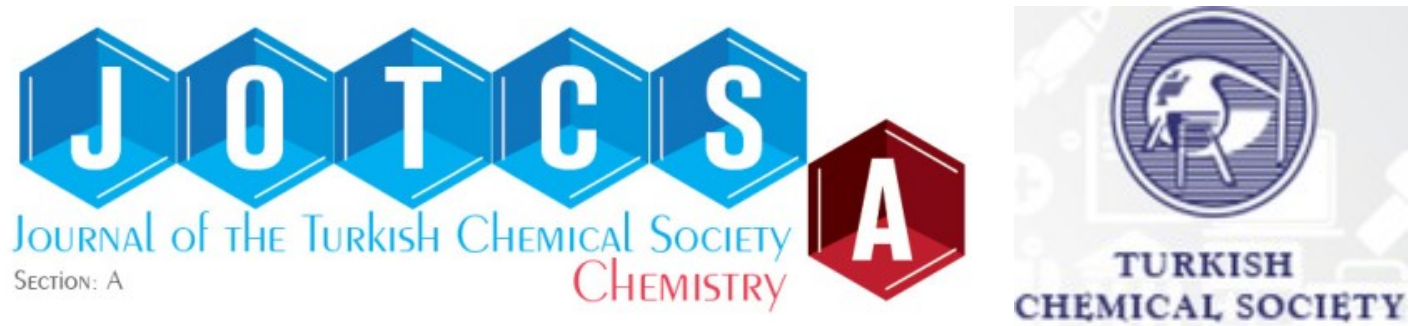

\title{
Antioxidant Enzyme Activities in Ascorbic Acid and Selenium Applied Hepatocellular Carcinoma Cells
}

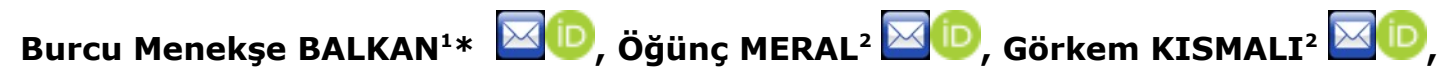

Tevhide SEL ${ }^{2}$

${ }^{1}$ Burdur Mehmet Akif Ersoy University, Faculty of Veterinary Medicine, Department of Biochemistry, Burdur - TURKEY

${ }^{2}$ Ankara University Faculty of Veterinary Medicine, Department of Biochemistry, Ankara - TURKEY

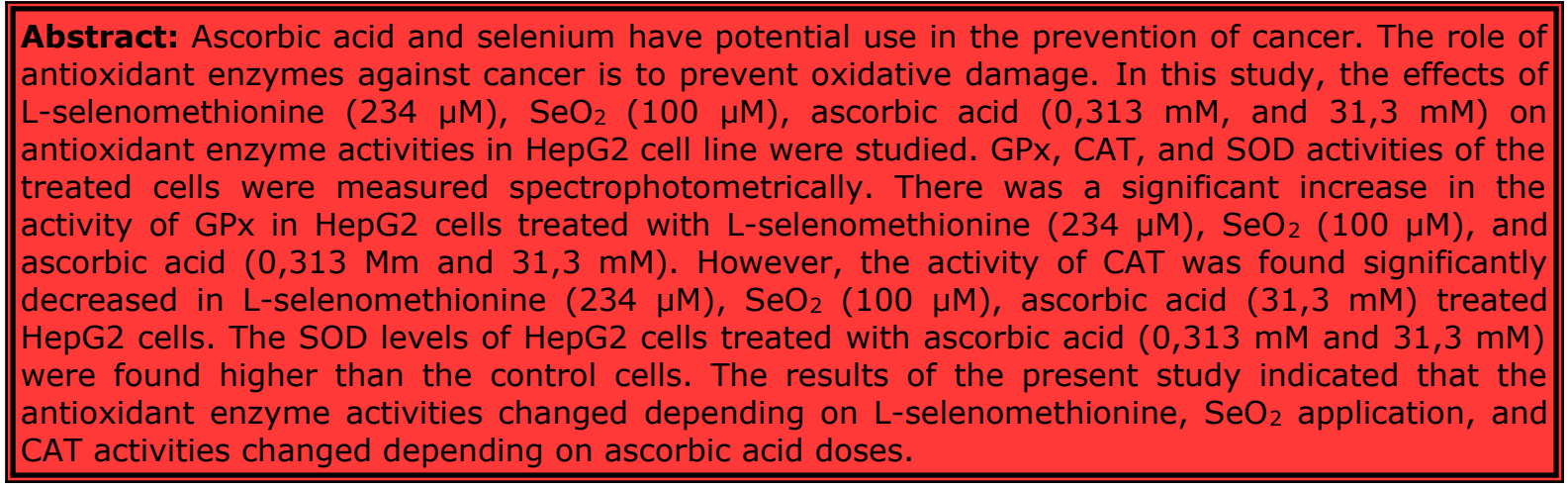

Key words: Antioxidant enzymes, Ascorbic acid, HepG2, Selenium

Submitted: April 21, 2020. Accepted: May 27, 2020.

Cite this: BALKAN BM, MERAL Ö, KISMALI G, SEL T. Antioxidant Enzyme Activities in Ascorbic Acid and Selenium Applied Hepatocellular Carcinoma Cells. JOTCSA. 2020;7(2):581-8.

DOI: https://doi.org/10.18596/jotcsa.724117.

*Corresponding author. E-mail: burcualpaslan@yahoo.com.

\section{INTRODUCTION}

Free radical species are formed as a result of reactions of oxygen and may play a role in tumor formation (1). On the other hand, overproduction of reactive oxygen species (ROS) can also induce the apoptotic pathway in the tumor cells, and this approach has effectively been used as a critical point for anticancer treatment (2). Depending on tumor type and degree, cancer cells exhibit different redox statuses. Because of these differences, the cell may be affected differently by the oxidants (3). Since oxidative stress may involve the etiology of cancer, agents that can prevent oxidative stress such as exogenous antioxidants have been extensively investigated to prove if they inhibit/reduce oxidative damage and prevent/slow cancer development (4). In addition to their protective effect on cancer, antioxidants like selenium (Se) and ascorbic acid (AA), exhibit pro-oxidant activity in cancer cells $(5,6)$. Se mediates ROS production in cancer cells, thus induces cytotoxicity $(7,8)$.

AA, a potent antioxidant, may act as a prooxidant when it reacts with metal ions in DNA. High doses of AA may prevent cancer, and it has been shown in limited studies that high dose ascorbate has promising results in the treatment of cancer (9). Because AA contributes to the production of superoxide and 
may produce ascorbyl radicals, it is considered as an essential pro-oxidant of free radical reactions (6).

Selenium, which is an essential element for many biological functions, has been shown to have a protective effect against cancer (10, $11)$. Selenium has various biological activities $(12,13)$ and can be found as organically bound selenium forms (e.g., selenomethionine, selenocysteine) or inorganic forms (e.g., selenate, selenite) (14). Selenoproteins that contain organically bound selenium are found in living organisms, including humans, and some of their roles are well identified $(15,16,17)$.

In the current study, it is aimed to investigate the effect of two different concentrations of AA and two different forms of selenium on antioxidant enzyme activities in the HepG2 cell line.

\section{MATERIALS AND METHODS}

\section{Cell Culture}

HepG2 cell line was used in this study (ATCC Cat No. HB- 8065). Cells were placed into 75$\mathrm{cm}^{2}$ tissue culture flasks and grown in RPMI 1640 Medium containing $10 \%$ Fetal Bovine Serum (FBS), $50 \mathrm{mg} / \mathrm{l}$ Gentamicin sulfate and $300 \mathrm{mg} / \mathrm{l}$ L-glutamine in a cell culture incubator at $37^{\circ} \mathrm{C}$ in the presence of $5 \% \mathrm{CO}_{2}$.

For the determination of the effect of compounds in question on antioxidant enzyme activities, $0.313 \mathrm{mM}$ and $31.3 \mathrm{mM}$ AA (Merck, Cat No: 100468), $234 \mu \mathrm{M}$ L-selenomethionine (Merck, Cat No: 561505), $100 \mu \mathrm{M} \mathrm{SeO}_{2}$ (Sigma, Cat no: S-9379) concentrations, which were observed to significantly change the cell viability in previous studies $(18,19)$, were applied to HepG2 cells. Only RPMI 1640 Medium (containing $10 \%$ FBS, 50 mg/l Gentamicin sulfate and $300 \mathrm{mg} / \mathrm{l}$ L-glutamine) was applied to the control group.

\section{Determination of Antioxidant Enzyme Activities}

After treatments with $\mathrm{AA}, \mathrm{SeO}_{2}$ and $\mathrm{L}-$ selenomethionine for $24 \mathrm{~h}$, cells were detached using a sterilized scrapper, lysed in ice-cold lysis buffer $(0.1 \mathrm{M}$ Tris $/ \mathrm{HCl}$, $\mathrm{pH} 7.4$, containing $0.5 \%$ Triton $X-100,5 \mathrm{mM} \beta$-Mercaptoethanol, $0.1 \mathrm{mg} / \mathrm{ml}$ serine proteases inhibitor Phenylmethylsulfonyl fluoride) and centrifuged at $14.000 \times \mathrm{g}$ for 5 minutes at $+4{ }^{\circ} \mathrm{C}$. The supernatant was collected and kept at $-80^{\circ} \mathrm{C}$ for CAT, SOD, and GPx analysis.
Superoxide dismutase (SOD) activities were determined using the SOD determination kit (Sigma-Aldrich, USA) according to the manufacturer's instructions. GPx activities were measured by spectrophotometric analysis at $340 \mathrm{~nm}$ according to the procedure described by Paglia and Valentine 1967 (20). CAT activity was also measured spectrophotometrically by the method stated by Aebi 1983 (21). This method is based on the measurement of the rate of decrease in the absorbance at $240 \mathrm{~nm}$ as the catalase enzyme breaks hydrogen peroxide down into water and oxygen. The rate decrease in absorbance is proportional to catalase enzyme activity. The specific activity of catalase is defined as $\mathrm{k} / \mathrm{g}$ protein. $\mathrm{k}$ value was calculated from the equation $k=0.1175 / t \quad(t=$ Time in seconds, which is required for reduction of absorbance from 0.45 to 0.40 ).

Protein concentration in the cell lysate was determined by Bradford assay (22). All enzyme activity values were divided by protein concentration for specific activity determination. All experiments were repeated in triplicate for each group. Mean values were shown in Table 1.

\section{Statistical Analysis}

Statistical analysis between treated and control groups was performed with variance analysis (ANOVA), and differences between the groups were determined with the Duncan post hoc test. $P$ values $<0.05$ were considered statistically significant.

\section{RESULTS}

\section{GPx and SOD Enzyme Activities in HepG2 cells}

GPx activities were significantly increased in HepG2 cells treated with 0.313 and $31.3 \mathrm{mM}$ $\mathrm{AA}, 234 \mu \mathrm{M}$ L-selenomethionine, and $100 \mu \mathrm{M}$ $\mathrm{SeO}_{2}$ compared to the control group (Figure 1). SOD activities were significantly increased in HepG2 cells at 0.313 and $31.3 \mathrm{mM}$ of $A A$ and $234 \mu \mathrm{M} \quad \mathrm{L}$-selenomethionine concentration compared to the control group (Figure 2). These results may indicate that increasing SOD activity 0.313 and $31.3 \mathrm{mM}$ of $\mathrm{AA}$ and $234 \mu \mathrm{M}$ L-selenomethionine have antioxidant effects in this concentration. Also, GPx levels are higher in L-selenomethionine-treated concentration than $\mathrm{SeO}_{2}$. Hence, we may conclude that Lselenomethionine is less toxic or has more potent antioxidant properties than $\mathrm{SeO}_{2}$, which is the inorganic form of selenium. The SOD activities of HepG2 cells treated with different doses of L-selenomethionine, $\mathrm{SeO}_{2}$ and $\mathrm{AA}$ in comparison to the control group are presented in Figure 2. 


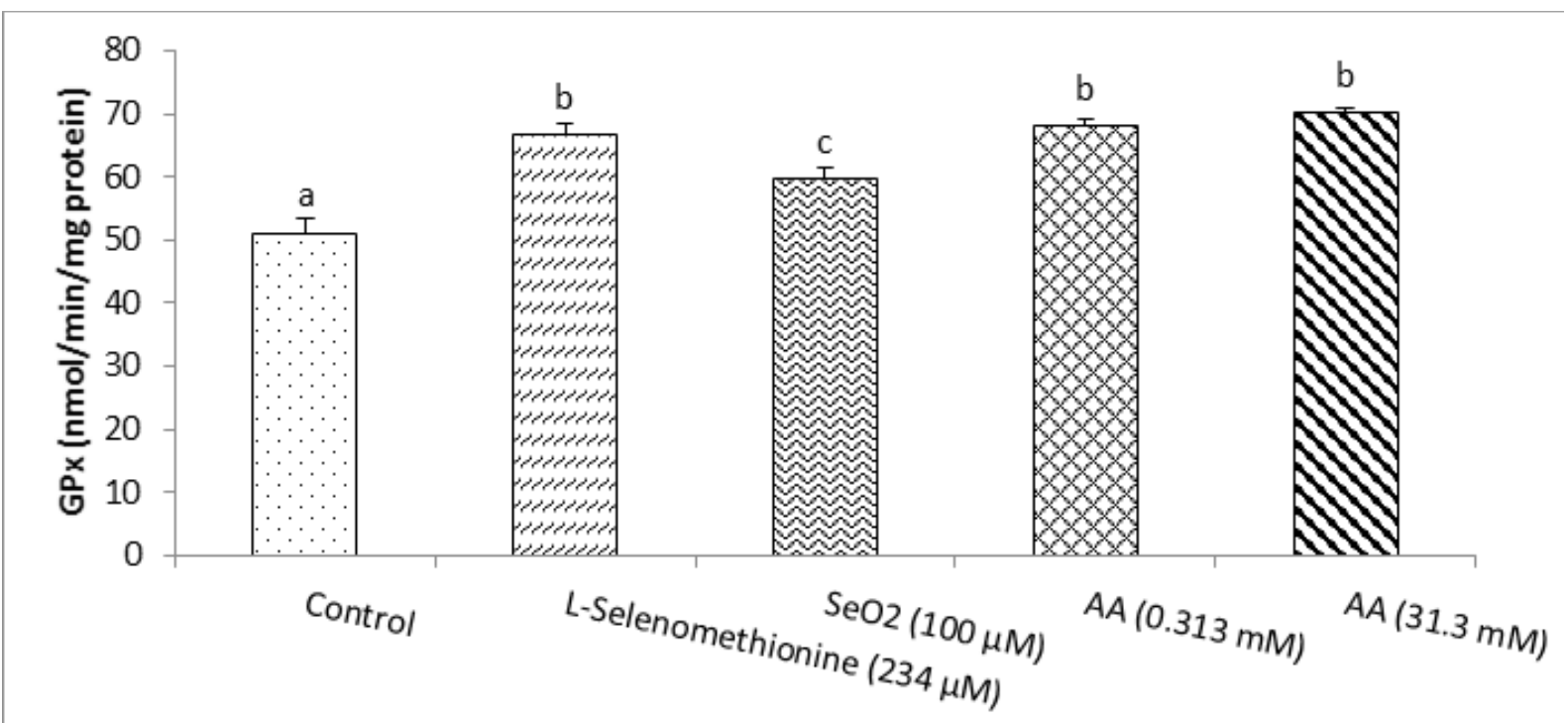

Figure 1. The GPx activities in HepG2 cells treated with $234 \mu \mathrm{M}$ L-selenomethionine, $100 \mu \mathrm{M} \mathrm{SeO}$, $0.313 \mathrm{mM}$, and $31.3 \mathrm{mM}$ AA (Different letters indicate the differences between the groups).

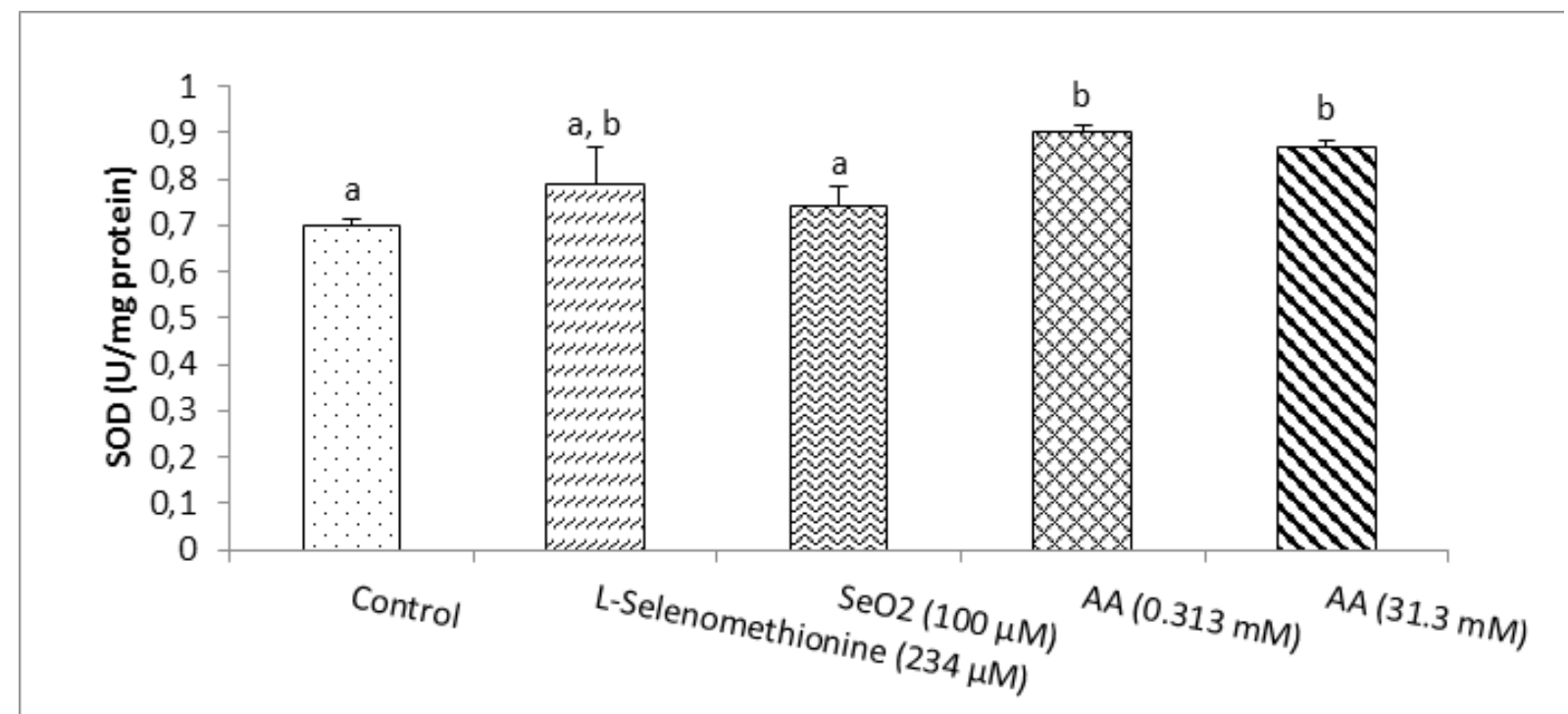

Figure 2. The SOD activities in HepG2 cells treated with $234 \mu \mathrm{M}$ L-selenomethionine, $100 \mu \mathrm{M}$ $\mathrm{SeO}_{2}, 0.313 \mathrm{mM}$, and $31.3 \mathrm{mM}$ AA (Different letters indicate the differences between the groups).

\section{CAT Enzyme Activities in treated HepG2 cells}

CAT activities were significantly increased in HepG2 cells only at $0.313 \mathrm{mM}$ AA concentration. CAT activities were significantly decreased in $31.3 \mathrm{mM} \mathrm{AA}$, L-selenomethionine, and $\mathrm{SeO}_{2}$ applied HepG2 cells compared to the control group (Figure 1 ). These results may indicate that depending on its dose, AA may have either antioxidant or pro-oxidant effects on HepG2 cells. Decreased activity of catalase represents the conversion of hydrogen peroxide to more toxic hydroxyl radicals. The CAT activities of HepG2 cells which were treated with different doses of L-selenomethionine, $\mathrm{SeO}_{2}$ and $\mathrm{AA}$ in comparison to the control group are presented in Figure 3.

$0.313 \mathrm{mM}$ and $31.3 \mathrm{mM}$ AA (Different letters indicate the differences between the groups). The results of the study are summarized in Table 1. 


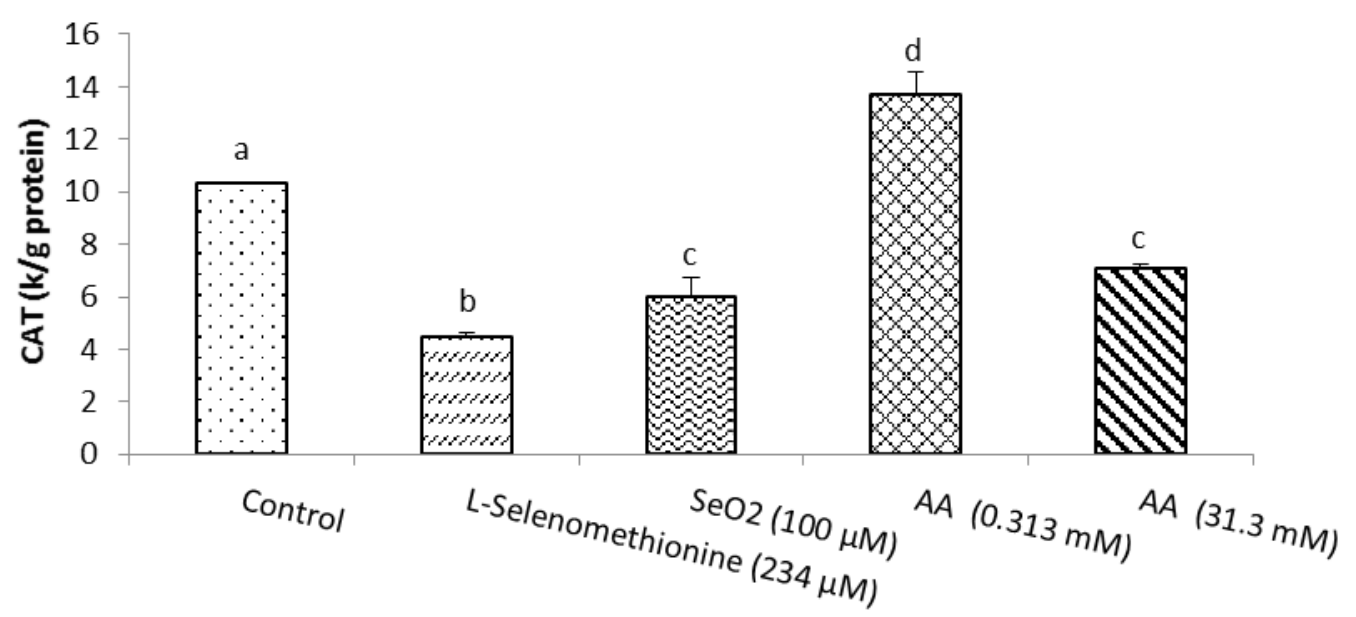

Figure 3. The CAT activities in HepG2 cells treated with $234 \mu \mathrm{M}$ L-selenomethionine, 100 $\mu \mathrm{M} \mathrm{SeO}, 0.313 \mathrm{mM}$ and $31.3 \mathrm{mM}$ AA (Different letters indicate the differences between the groups)

Table 1. The GPx, SOD and CAT enzyme activities of HepG2 cells treated with $234 \mu \mathrm{M}$ Lselenomethionine, $100 \mu \mathrm{M} \mathrm{SeO}_{2}, 0.313 \mathrm{mM}$ and $31.3 \mathrm{mM}$ AA.

GROUPS

Control group L-Selenomethionine (234 $\boldsymbol{\mu M})$

$\mathrm{SeO}_{2}(100 \mu \mathrm{M})$

AA $(0.313 \mathrm{mM})$

GPX $(X \pm S D)$

SOD (X \pm SD)

CAT (X \pm SD)

$\begin{array}{lll}51.1 \pm 2.32^{\mathrm{a}} & 0.70 \pm 0.014^{\mathrm{a}} & 10.3 \pm 0.035^{\mathrm{a}} \\ 66.7 \pm 1.85^{\mathrm{b}} & 0.79 \pm 0.077^{\mathrm{a}, \mathrm{b}} & 4.47 \pm 0.16^{\mathrm{b}} \\ 59.7 \pm 1.79^{\mathrm{c}} & 0.74 \pm 0.042^{\mathrm{a}} & 5.99 \pm 0.714^{\mathrm{b}} \\ 68.1 \pm 0.9^{\mathrm{b}} & 0.9 \pm 0.014^{\mathrm{b}} & 13.7 \pm 0.86^{\mathrm{d}} \\ 70.1 \pm 0.9^{\mathrm{b}} & 0.87 \pm 0.011^{\mathrm{b}} & 7.09 \pm 0.15^{\mathrm{c}}\end{array}$

Data are presented as (Mean \pm SD). SD: Standard deviation. Statistical analysis was performed using one-way ANOVA with post hoc Duncan test. $P$ values<0,05 were considered statistically significant (GPx : $\mathrm{nmol} / \mathrm{min} / \mathrm{mg}$ protein; SOD: U/mg of protein; CAT: $\mathrm{k} / \mathrm{g}$ of protein). Different letters in the same column are statistically significant.

\section{DISCUSSION AND CONCLUSION}

As oxidative stress causes DNA damage, it has a role in cancer pathogenesis (23). The antioxidant enzymes CAT and GPx can scavenge hydrogen peroxide, which is produced by SOD from superoxide radical. In some cases, hydrogen peroxide is converted to highly toxic hydroxyl radicals by Fenton reaction due to the low CAT level (24). For the normal cellular function, there should be an appropriate balance between $\mathrm{Cu} / \mathrm{Zn}$-superoxide dismutase $(\mathrm{Cu} / \mathrm{Zn}-\mathrm{SOD})$, catalase, and seleniumglutathione peroxidase activities. CAT and SOD activity could demonstrate the positive or negative balance of the antioxidant defense system (25).

On the hepatic metastasis model, Heukamp et al. (26) found that vitamins A (retinol), C (ascorbic acid) and E (alpha-tocopherol) increased GPx and SOD activities and decreased thiobarbituric acid-reactive substances (TBARS) levels. They concluded that these vitamins prevent oxidative stress in hepatocytes. In a study on young and aged rats, they found that the AA level decreased due to the increase in lipid peroxidation and MDA levels (27).

Although it is considered to be an antioxidant agent, at pharmacological doses (0.3-20 mM) $A A$, have been reported to be selectively toxic to cancer cells by producing ascorbate radicals, and inducing $\mathrm{H}_{2} \mathrm{O}_{2}$ formation (28). AA has also been reported in other studies to have cytotoxic effects on various types of cancer cells through a hydrogen peroxide generation $(5,29,30,31)$. Studies showed that specific protein transcription factors significantly decreased, and iron metabolism disrupted after AA treatment in colon cancer cells that are involved in cancer progression $(32,33)$. In 
Ryszawy et al. (34) study, sodium ascorbate showed anti-tumor activity in glioblastoma multiforme cells. Gao et al. (35) demonstrated that AA could lead to liver cancer cells' death via intracellular reductive stress.

Increasing ROS production and oxidation, $\mathrm{Se}$ is known to induce apoptotic cell death in cancer cells $(36,37)$. Se, which is an essential element for many biological functions, has been shown to have cancer-protective effects in epidemiological and experimental animal studies. In addition to its protective effect against cancer, Se shows prooxidant activity and increased oxidative stress in cancer cells (38).

Wu et al. (39), demonstrated the therapeutic effect of selenite on peritoneal cancer in a mouse model. They indicated that selenite induced ROS production depending on its dose in the $\mathrm{H} 22$ cells and $4 \mathrm{mg} \mathrm{Se} / \mathrm{kg}$ could be more effective than that of cisplatin in killing cancer cells. The mechanism of $\mathrm{Se}$ is related to endogenously formed selenium nanoparticles and its effect to hijack the Trx- and Grx-coupled GSH systems to produce ROS to kill cancer cells. Some organic Se components such as selenoamino acids, selenoproteins, and synthetic organic Se compounds have been reported to have cancer-protective effects (40, 41). Many preclinical, epidemiological studies and experimental animal models supported that Se compounds play a protective role against cancer. To date, studies have demonstrated the importance of the dose, which is administered, and the chemical structure of Se, which is used to determine the protective activity of Se components from cancer (42).

It is thought that there are many mechanisms in the anticancer activity of Se (43). But it was revealed that cell deaths that are related to $\mathrm{Se}$ applications were associated with ROS production (37, 38, 44, 45), and apoptotic cell death due to increased ROS production was observed through the caspase-independent apoptotic pathway (46). Estevez et al. (47) investigated the effects of chitosan-stabilized selenium nanoparticles, which were compared with other selenium-containing species on cell proliferation, apoptosis, and cell cycle pattern in HepG2 cells. They compared the effect of different type of Se compounds and concluded that cells which were exposed to Se(IV) showed strong induction of apoptosis and a significant population of cells when they are compared to control cells.

In our study, while the effects of AA on CAT activity were found to be dose-dependent, no changes were found in GPx and SOD activities. GPX activities increased, but CAT activities decreased in L-selenomethionine, and $\mathrm{SeO}_{2}$ applied to HepG2 cells when they are compared to the control group. L-selenomethionine generated a significant increase in GPx activity than $\mathrm{SeO}_{2}$. There were no statistical differences in SOD activity between L-selenomethionine and $\mathrm{SeO}_{2}$ applied HepG2 cells. Compared to the control group: GPX activities increased in HepG2 cells treated with L-selenomethionine, $\mathrm{SeO}_{2}$, and different doses of AA, but CAT activities decreased in all groups but increased in $0.313 \mathrm{mM} \mathrm{AA}$ applied cells compared to the control group.

The results of this study indicated that $L$ selenomethionine, $\mathrm{SeO}_{2}$, and $\mathrm{AA}$ application increase GPx enzyme activities in HepG2 cells. $\mathrm{L}$-selenomethionine and $\mathrm{SeO}_{2}$ decrease CAT enzyme activities but do not chance SOD enzyme activities. SOD enzyme activities are increased in both $0.313 \mathrm{mM}$ and $31.3 \mathrm{mM} \mathrm{AA}$ concentrations. Depending on its doses, AA effects CAT enzyme activities. $0.313 \mathrm{mM} \mathrm{AA}$ increases, and $31.3 \mathrm{mM}$ decreases CAT enzyme activities in HepG2 cells.

\section{ACKNOWLEDGMENTS}

This study was presented in the $1^{\text {st }}$ International Conference on Natural Products for Cancer Prevention and Therapy, 31 August2 September 2015, Istanbul, Turkey.

\section{REFERENCES}

1. Traber MG, Atkinson J. Vitamin E, antioxidant and nothing more. Free Radic Biol Med. 2007;43(1):4-15. Doi:

10.1016/j.freeradbiomed.2007.03.024.

2. Zou Z, Chang $\mathrm{H}$, Li H, Wang S. Induction of reactive oxygen species: an emerging approach for cancer therapy. Apoptosis. 2017;22(11):1321-35. doi: $10.1007 /$ s10495-017-1424-9.

3. Hatem E, Azzi S, El Banna N, He T, Heneman-Masurel A, Vernis $L$, et al. Auranofin/Vitamin C: A novel drug combination targeting triple-negative breast cancer. J Natl Cancer Inst. $2019 ; 111(6): 597-608$. doi: $10.1093 / i j e / d j y 149$.

4. Shaaban S, Ashmawy AM, Negm A, Wessjohann LA. Synthesis and biochemical studies of novel organic selenides with increased selectivity for hepatocellular carcinoma and breast adenocarcinoma. Eur J Med Chem. 2019;179:515-526.

doi:10.1016/j.ejmech.2019.06.075.

5. Du J, Martin SM, Levine M, Wagner BA, Buettner GR, Wang $\mathrm{SH}$, et al. Mechanisms of ascorbate-induced cytotoxicity in pancreatic cancer. Clin Cancer Res. 2010;16(2):509-20. doi: 10.1158/1078-0432.CCR-09-1713.

6. Paolini M, Pozzetti L, Pedulli GF, Marchesi E, Cantelli-Forti G. The nature of prooxidant activity of vitamin C. Life Sci. 1999;64(23):273-278. Doi: 10.1016/s0024-3205(99)00167-8. 
7. Fernandes AP, Gandin V. Selenium compounds as therapeutic agents in cancer. Biochim Biophys Acta - Gen Subj. 2015;1850(8):1642-60. doi: $10.1016 / j$.bbagen.2014.10.008.

8. Misra S, Boylan M, Selvam A, Spallholz JE, Björnstedt $M$. Redox-active selenium compoundsfrom toxicity and cell death to cancer treatment. Nutrients. 2015;7(5):3536-56. doi: 10.3390/nu7053536.

9. Head KA. Ascorbic acid in the prevention and treatment of cancer. Altern Med Rev. 1998;3(3):17486. PMID: 9630735.

10. Combs GF. Status of selenium in prostate cancer prevention. Br J Cancer. 2004;91(2):195-9. Doi: $10.1038 /$ sj.bjc. 6601974

11. Knekt P, Marniemi J, Teppo L, Heliövaara M, Aromaa A. Is low selenium status a risk factor for lung cancer? Am J Epidemiol. 1998;148(10):975-82. Doi: $10.1093 / o x f o r d j o u r n a l s . a j e . a 009574$.

12. Mandrioli J, Michalke B, Solovyev N, Grill P, Violi F, Lunetta $C$, et al. Elevated levels of selenium species in cerebrospinal fluid of amyotrophic lateral sclerosis patients with disease-associated gene mutations. Neurodegener Dis. 2017;17(4-5):171-80. doi: $10.1159 / 000460253$.

13. Vinceti $M$, Chiari $A$, Eichmüller $M$, Rothman $\mathrm{KJ}$, Filippini T, Malagoli $C$, et al. A selenium species in cerebrospinal fluid predicts conversion to Alzheimer's dementia in persons with mild cognitive impairment. Alzheimer's Res Ther. 2017;9(1):100. doi: 10.1186/s13195-017-0323-1.

14. Gammelgaard B, Jackson MI, Gabel-Jensen C. Surveying selenium speciation from soil to cellforms and transformations. Analytical and Bioanalytical Chemistry. 2011;399:1743-63. doi: $10.1007 / \mathrm{s} 00216-010-4212-8$.

15. Brigelius-Flohé $\mathrm{R}$, Flohé L. Selenium and redox signaling. Arch Biochem Biophys. 2017;617:48-59. doi: 10.1016/j.abb.2016.08.003.

16. Hatfield DL, Tsuji PA, Carlson BA, Gladyshev VN. Selenium and selenocysteine: Roles in cancer, health, and development. Trends Biochem Sci. 2014;39(3):112-20. doi: 10.1016/j.tibs.2013.12.007.

17. Labunskyy VM, Hatfield DL, Gladyshev VN. Selenoproteins: Molecular pathways and physiological roles. Physiol Rev. 2014;94:739-77. doi: 10.1152/physrev.00039.2013.

18. Balkan BM, Sel T. Vitamin C'nin HepG2 hücrelerinde apoptozis üzerine etkileri. Ankara Üniv Vet Fak Derg. 2014;61:237-41.

19. Balkan BM. HepG2 hücrelerinde selenyum ve vitamin C'nin apoptosis üzerine etkileri [Doktora Tezi]. [Ankara]: Ankara Üniversitesi; 2012.

20. Paglia DE, Valentine WN. Studies on the quantitative and qualitative characterization of erythrocyte glutathione peroxidase. J Lab Clin Med. 1967;70(1):158-69. PMID: 6066618

21. Aebi HE. Catalase in: H.U. Bermeyer (Hrsy).
Methods of enzymatic analysis. Verlag Chemie; Weinheim, Bd. III; 1983. p. 273-286.

22. Bradford M. A rapid and sensitive method for the quantitation of microgram quantities of protein utilizing the principle of protein-dye binding. Anal Biochem. 1976;72(1-2):248-54. doi.org/10.1016/0003-2697(76)90527-3.

23. Athreya K, Xavier MF. Antioxidants in the treatment of cancer. Nutrition and Cancer.

2017;69:1099-104. doi:

10.1080/01635581.2017.1362445

24. Guo Dong Mao, Thomas PD, Lopaschuk GD, Poznansky MJ. Superoxide dismutase (SOD)-catalase conjugates. Role of hydrogen peroxide and the fenton reaction in SOD toxicity. J Biol Chem.

1993;268(1):416-20. PMID: 8380162.

25. Michiels C, Raes M, Toussaint O, Remacle J. Importance of SE-glutathione peroxidase, catalase, and $\mathrm{CU} / \mathrm{ZN}-\mathrm{SOD}$ for cell survival against oxidative stress. Free Radic Biol Med. 1994;17(3):235-48. Doi 10.1016/0891-5849(94)90079-5.

26. Heukamp I, Kilian M, Gregor JI, Neumann A, Jacobi CA, Guski $\mathrm{H}$, et al. Effects of the antioxidative vitamins $A, C$ and $E$ on liver metastasis and intrametastatic lipid peroxidation in bop-induced pancreatic cancer in Syrian hamsters. Pancreatology. 2005;5(4-5):403-9. Doi: 10.1159/000086541.

27. Van Der Loo B, Bachschmid M, Spitzer V, Brey $L$, Ullrich $V$, Lüscher TF. Decreased plasma and tissue levels of vitamin $C$ in a rat model of aging Implications for antioxidative defense. Biochem Biophys Res Commun. 2003;303(2):483-7. Doi: 10.1016/s0006-291x(03)00360-7.

28. Chen $\mathrm{Q}$, Espey MG, Krishna MC, Mitchell JB, Corpe CP, Buettner GR, et al. Pharmacologic ascorbic acid concentrations selectively kill cancer cells: Action as a pro-drug to deliver hydrogen peroxide to tissuse. Proc Natl Acad Sci USA. 2005;102(38):13604-9. Doi: 10.1073/pnas.0506390102.

29. Chen P, Stone J, Sullivan G, Drisko JA, Chen $Q$. Anti-cancer effect of pharmacologic ascorbate and its interaction with supplementary parenteral glutathione in preclinical cancer models. Free Radic Biol Med. 2011;51(3):681-7. doi:

10.1016/j.freeradbiomed.2011.05.031.

30. Du J, Cullen JJ, Buettner GR. Ascorbic acid: Chemistry, biology and the treatment of cancer.

Biochim Biophys Acta - Rev Cancer.

2012;1826(2):443-57. doi:

10.1016/j.bbcan.2012.06.003.

31. Levine M, Padayatty SJ, Espey MG. Vitamin C: A concentration-function approach yields pharmacology and therapeutic discoveries. Adv Nutr. 2011;2(2):78-88. doi: 10.3945/an.110.000109.

32. Pathi SS, Lei $P$, Sreevalsan $S$, Chadalapaka G, Jutooru I, Safe S. Pharmacologic doses of ascorbic acid repress specificity protein (Sp) transcription factors and Sp-regulated genes in colon cancer cells. Nutr Cancer. 2011;63(7):1133-42. doi: 10.1080/01635581.2011.605984. 
33. Schoenfeld JD, Sibenaller ZA, Mapuskar KA, Wagner BA, Cramer-Morales KL, Furqan M, et al. $\mathrm{O}_{2} \cdot-$ and $\mathrm{H}_{2} \mathrm{O}_{2}$-mediated disruption of $\mathrm{Fe}$ metabolism causes the differential susceptibility of NSCLC and GBM cancer cells to pharmacological ascorbate. Cancer Cell. 2017;31(4):487-500. doi: 10.1016/j.ccell.2017.02.018.

34. Ryszawy D, Pudełek M, Catapano J, Ciarach M, Setkowicz Z, Konduracka E, et al. High doses of sodium ascorbate interfere with the expansion of glioblastoma multiforme cells in vitro and in vivo. Life Sci. 2019;232:116657. doi: 10.1016/j.Ifs.2019.116657.

35. Gao $P$, Zhang $H$, Dinavahi $R$, Li $F$, Xiang $Y$, Raman V, et al. HIF-Dependent antitumorigenic effect of antioxidants in vivo. Cancer Cell. 2007;12(3):2308. Doi: 10.1016/j.ccr.2007.08.004.

36. Susin SA, Daugas E, Ravagnan L, Samejima $\mathrm{K}$, Zamzami N, Loeffler $M$, et al. Two distinct pathways leading to nuclear apoptosis. J Exp Med. 2000;192(4):571-9. Doi: 10.1084/jem.192.4.571.

37. Ug uz AC, Naziroglu M, Espino J, Bejarano I, González D, Rodríguez $A B$, et al. Selenium modulates oxidative stress-induced cell apoptosis in human myeloid HL-60 cells through regulation of calcium release and caspase- 3 and -9 activities. J Membr Biol. 2009;232(1-3):15-23. doi: 10.1007/s00232-0099212-2.

39. Wu X, Zhao G, He Y, Wang W, Yang CS, Zhang J. Pharmacological mechanisms of the anticancer action of sodium selenite against peritoneal cancer in mice. Pharmacol Res. 2019;147:104360. doi: 10.1016/j.phrs.2019.104360.

40. Chen T, Zheng W, Wong YS, Yang F. Mitochondria-mediated apoptosis in human breast carcinoma MCF-7 cells induced by a novel selenadiazole derivative. Biomed Pharmacother. 2008;62(2):77-84. doi:

10.1016/j.biopha.2007.12.002.

41. Rayman MP. The importance of selenium to human health. Lancet. 2000;356(9225):233-41. Doi: 10.1016/S0140-6736(00)02490-9.

42. El-Bayoumy K, Sinha R. Mechanisms of mammary cancer chemoprevention by organoselenium compounds. Mutat Res. 2004;551(12):181-97. Doi: 10.1016/j.mrfmmm.2004.02.023.

43. Whanger PD. Selenium and its relationship to cancer: an update. $\mathrm{Br}$ J Nutr. 2004;91(1):11-28. Doi: 10.1079/bjn20031015.

44. Gopee N V., Johnson VJ, Sharma RP. Sodium selenite-induced apoptosis in murine B-lymphoma cells is associated with inhibition of protein kinase C$\delta$, nuclear factor $\kappa B$, and inhibitor of apoptosis protein. Toxicol Sci. 2004;78(2):204-14. Doi: 10.1093/toxsci/kfh072.

45. Shilo S, Tirosh O. Selenite activates caspaseindependent necrotic cell death in Jurkat $T$ cells and J774.2 macrophages by affecting mitochondrial oxidant generation. Antioxidants Redox Signal. 2003;5(3):273-9. Doi:

$10.1089 / 152308603322110850$.

46. Rudolf E, Rudolf K, Červinka M. Selenium activates p53 and p38 pathways and induces caspase-independent cell death in cervical cancer cells. Cell Biol Toxicol. 2008;24(2):123-41. Doi: 10.1007/s10565-007-9022-1.

47. Estevez H, Garcia-Lidon JC, Luque-Garcia JL, Camara C. Effects of chitosan-stabilized selenium nanoparticles on cell proliferation, apoptosis and cell cycle pattern in HepG2 cells: Comparison with other selenospecies. Colloids Surfaces B Biointerfaces. 2014;122:184-93. doi: 10.1016/j.colsurfb.2014.06.062. 
